\title{
Tidal flood hazard in coastal area of Tangerang Regency
}

\author{
Wibi Hanif Wibowo ${ }^{1}$, Ratna Saraswati ${ }^{1 *}$, and Nurul Sri Rahatiningtyas ${ }^{1}$ \\ ${ }^{1}$ Geography Department, Faculty of Mathematics and Natural Science, Universitas Indonesia, \\ Depok, 16424, Indonesia.
}

\begin{abstract}
Tidal flood is one of the threats to the coastal areas, especially the north coast of Java. The coastal area of Tangerang Regency itself has a history of tidal flood events that occur every year. The tidal flood hazard level can be measured based on the flood characteristic, which includes flood height, flood duration, and flood frequency. Flood characteristic data are obtained by purposive sampling where the tidal flood occurred. Those data are interpolated using Inverse Distance Weighted (IDW) and overlaid to get the tidal flood hazard level in coastal area of Tangerang Regency. The class of non-hazardous dominates Tangerang Regency. The class has 9,727 hectares or $75 \%$ of the total coastal area of Tangerang Regency. While the high-class hazard has an area of 1,149 hectares or $9 \%$ of the total coastal area of Tangerang Regency. Hazard level may increase in some regions which close to the river mouth. The increasing of hazard level can also be indicated by a low altitude area. Based on the calculation of hazard equilibrium value, the coastal area of Tangerang Regency is dominated by low-class hazard level. There are 12 villages with low-class of hazard level.
\end{abstract}

\section{Introduction}

Tidal flood is a flood that comes from high tides. Tidal flood inundates the land with water which is a combination of brackish water and saltwater [1]. Tidal flood can occur in the rainy season or dry season [2]. This indicates that rainfall is not a significant factor causing a tidal flood. The moon's gravitational force is the most influential factor in the occurrence of tides, which then causes a tidal flood. The gravitational force of the moon produces something called tidal forces. Tidal forces then cause seawater on earth to "enlarge" on the side closest and furthest from the moon [3]. The occurrence of a tidal flood is one type of hazard because it can damage the environment [4].

The northern region of Java is an area prone to tidal flood due to its condition that has a sloping topography so that flooding can quickly get into the land [5]. This is evidenced by the number of tidal flood events in both regencies and cities adjacent to the sea, such as North Jakarta, Semarang City, Tangerang Regency, and Probolinggo Regency Pekalongan City, and Surabaya City.

Coastal Tangerang Regency is a region with a low topography. Due to its low topography, the coastal area of Tangerang Regency is an area prone to tidal flood disasters [5]. Tidal

\footnotetext{
*Corresponding author : ratna.saraswati@ui.ac.id
} 
floods that occur on the coast of Tangerang Regency are the result of direct or indirect seawater. The indirect seawater can enter through rivers and waterways. Tidal floods that occur on the coast of Tangerang Regency are annual or even monthly. Based on the survey, villages with tidal incidents occur each month, for example in Dadap Village, East Kosambi Village, West Kosambi Village, Tanjung Pasir Village, and Tanjung Anom Village.

Coastal community development is stated in Tangerang Regency's Regional Long-Term Development (RPJPD). It is written that there is a strategy to increase public awareness in anticipating the threat of hazard and tidal flood mitigation. Tidal flood in the coastal area of Tangerang Regency is an annual or even monthly event. In 2019, the Tangerang Regency Regional Disaster Management Agency stated that several sub-districts are prone to tidal flood, including sub-districts of Teluknaga, Kosambi, Mauk, and Sukadiri. There are many damaged beaches caused by tidal floods and abrasion on the beaches in the Tangerang Regency coast [6]. Tidal flood impacts coastal communities, such as people whose houses are inundated, preferring to clean their houses first rather than work. Local people also raised their houses affected by tidal floods. Therefore, it is necessary to research the hazard level of tidal flood to achieve tidal flood mitigation properly in every location inundated by tidal flood. This study aims to analyze the hazard level of tidal flood in the coastal area of Tangerang Regency.

\section{Method}

The data required are the characteristics of flooding in the form of flood height, flood duration, and flood frequency in a year [7]. Data collection is assisted by an application called Avenza Map to put a point with certain values on each location. Determination of sample points using purposive sampling based on information on areas inundated by tidal flood and limited by 400 x $400 \mathrm{~m}$ grid. Values from each sample point are obtained by interview using a questionnaire. Data of flood characteristics are then interpolated using the Inverse Distance Weighted (IDW) method using ArcMap 10.4 software. The inundated area boundary is delineated by sample points in the outermost grid, which is not inundated by flood. The class division results are then overlaid based on the specified scoring and weighting in Table 1.

Table 1. Hazard level parameter [7]

\begin{tabular}{|c|c|c|c|}
\hline Flood Height $(\mathrm{cm})$ & Weight & Score & Class \\
\hline$<20$ & \multirow{3}{*}{$40 \%$} & 1 & Low \\
\hline $20-40$ & & 2 & Moderate \\
\hline$>40$ & & 3 & High \\
\hline $\begin{array}{l}\text { Flood Duration } \\
\text { (hours) }\end{array}$ & Weight & Score & Class \\
\hline$<5$ & \multirow{3}{*}{$30 \%$} & 1 & Low \\
\hline $5-10$ & & 2 & Moderate \\
\hline$>10$ & & 3 & High \\
\hline $\begin{array}{l}\text { Flood Frequency } \\
\text { (times) }\end{array}$ & Weight & Score & Class \\
\hline$<3$ & \multirow{3}{*}{$30 \%$} & 1 & Low \\
\hline $3-6$ & & 2 & Moderate \\
\hline$>6$ & & 3 & High \\
\hline
\end{tabular}




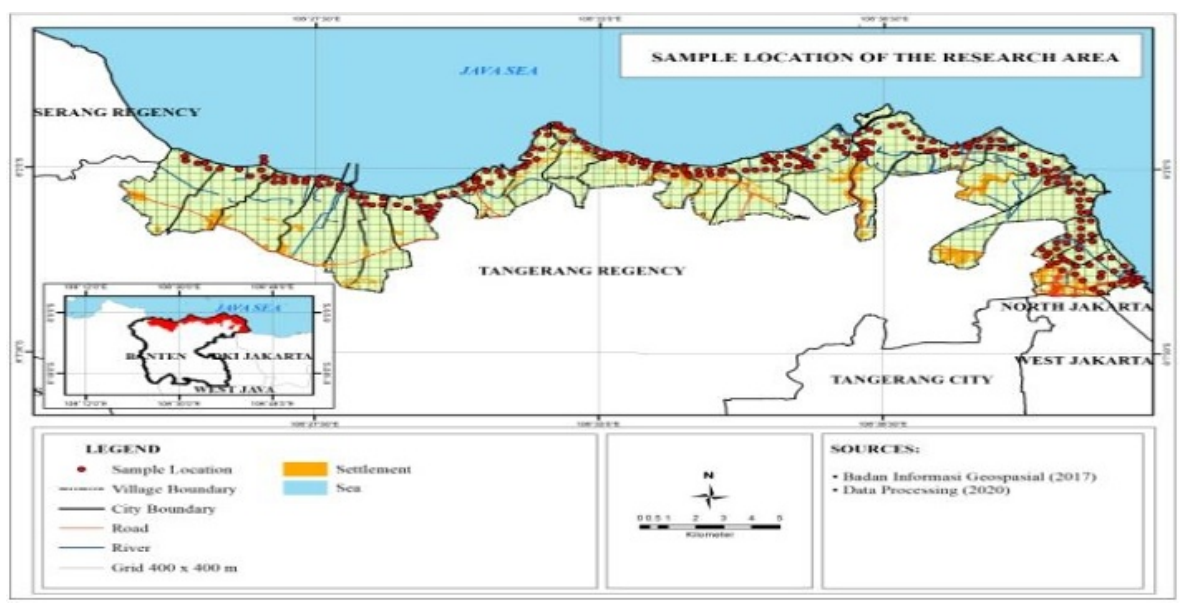

Fig. 1. Sample location of research area

The hazard level in each village is determined by the formula below to obtain how much the village was affected by flooding [8]:

Information:

$$
\mathrm{H}=\frac{\sum A n \times H n}{A \text { Total }}
$$

$\mathrm{H} \quad$ = hazard equilibrium value

An $\quad=$ area at flood hazard level (ha)

Hn = score at flood hazard level (high:4, moderate: 3, low: 2, non-hazardous: 1)

A total $=$ measured village area (ha)

\section{Results and discussion}

\subsection{Flood height}

The height of tidal flood in the coastal area of Tangerang Regency was obtained by interviewing respondents based on the determined sample points. The known sample points are then interpolated using IDW. Based on the sample point in Table 2, three classes of flood height were obtained, namely low $(<20 \mathrm{~cm})$, moderate $(20-40 \mathrm{~cm})$, and high $(>40 \mathrm{~cm})$. The interpolation result can be seen in Figure 2.

Table 2. Sample points based on tidal flood height

\begin{tabular}{|c|c|c|}
\hline Flood Height $(\mathrm{cm})$ & Number of Sample Points & Percentage (\%) \\
\hline$<20$ & 25 & 18 \\
\hline $20-40$ & 38 & 28 \\
\hline$>40$ & 73 & 54 \\
\hline Total & 136 & 100 \\
\hline
\end{tabular}

Low-class flood height has an area of 840 hectares or $26 \%$ of the total inundated area. Moderate class flood height has an area of 887 hectares or $27 \%$ of the total inundated area. While the high-class flood height has an area of 1,529 hectares or $47 \%$ of the total inundated 
area. High-class flood height dominates in area of altitude less than $20 \mathrm{~cm}$ above sea level.. Moderate and low-class flood height are mostly found at an altitude of more than $20 \mathrm{~cm}$ above sea level.

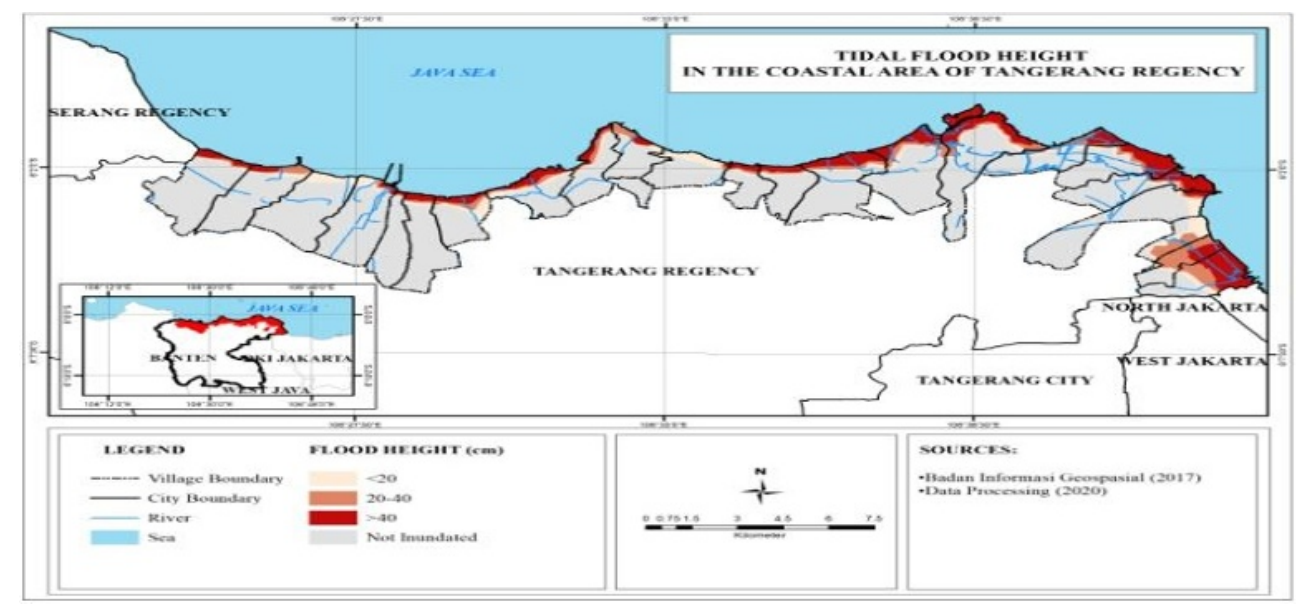

Fig. 2. Tidal flood height in coastal area of Tangerang Regency

\subsection{Flood duration}

The length of flooding of tidal flood in the coastal areas of Tangerang Regency was obtained by interviewing respondents based on the determined sample points. The known sample points are then interpolated using IDW. Based on the sample points in Table 3, three classes of flood height were obtained, namely low ( $<5$ hours), moderate (5-10 hours), and high ( $>10$ hours). The interpolation result can be seen in Figure 3.

Table 3. Sample points based on tidal flood duration

\begin{tabular}{|c|c|c|}
\hline Flood Duration (hours) & Number of Sample Points & Percentage (\%) \\
\hline$<5$ & 69 & 51 \\
\hline $5-10$ & 56 & 41 \\
\hline$>10$ & 11 & 8 \\
\hline Total & 136 & 100 \\
\hline
\end{tabular}

Low-class flood duration has an area of 2,176 hectares or $67 \%$ of the total inundated area. Flood duration with moderate class has an area of 785 hectares or $24 \%$ of the total area of inundated areas. While the flood duration with a high-class has an area of 294 hectares or $10 \%$ of the total inundated area. Based on the survey, flood duration to recede can be affected by the drainage. Tidal flood that gets into the settlement area tend to take longer to recede due to poor drainage in settlement area. Low-class flood duration dominated the western part of the coastal area of Tangerang Regency. Whereas eastward flood duration tends to increase from moderate to high-class. 


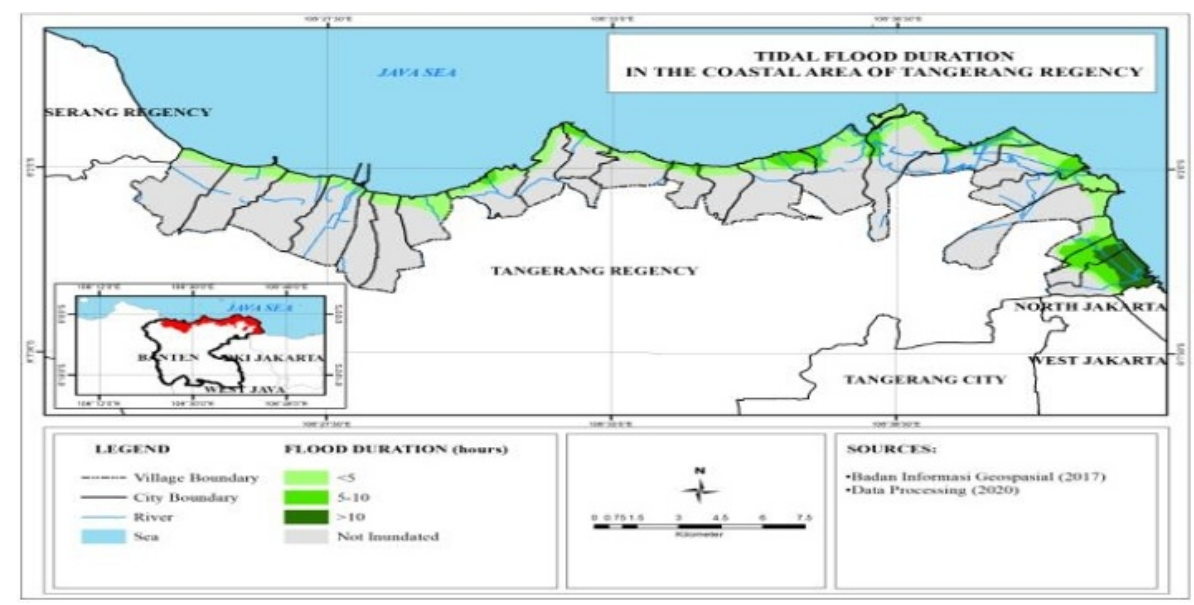

Fig. 3. Tidal flood duration in coastal area of Tangerang Regency

\subsection{Flood frequency}

The frequency of tidal flood in the coastal areas of Tangerang Regency was obtained by interviewing respondents based on a predetermined sample point. The known sample points are then interpolated using IDW. Based on the sample points in Table 4, three flood frequency classes were obtained in one-year incident, namely low ( $<3$ times), moderate (3-6 times), and high ( $>6$ times). The interpolation result can be seen in Figure 4.

Table 4. Sample points based on tidal flood frequency

\begin{tabular}{|c|c|c|}
\hline Flood Frequency (times) & Number of Sample Points & Percentage (\%) \\
\hline$<3$ & 36 & 26 \\
\hline $3-6$ & 35 & 26 \\
\hline$>6$ & 65 & 48 \\
\hline Total & 136 & 100 \\
\hline
\end{tabular}

The frequency of low-class flood has an area of 2,176 hectares or $67 \%$ of the total inundated area. The frequency of moderate class flooding has an area of 785 hectares or $24 \%$ of the total inundated area. Whereas the frequency of high-class flood has an area of 294 hectares or $9 \%$ of the total area inundated. 


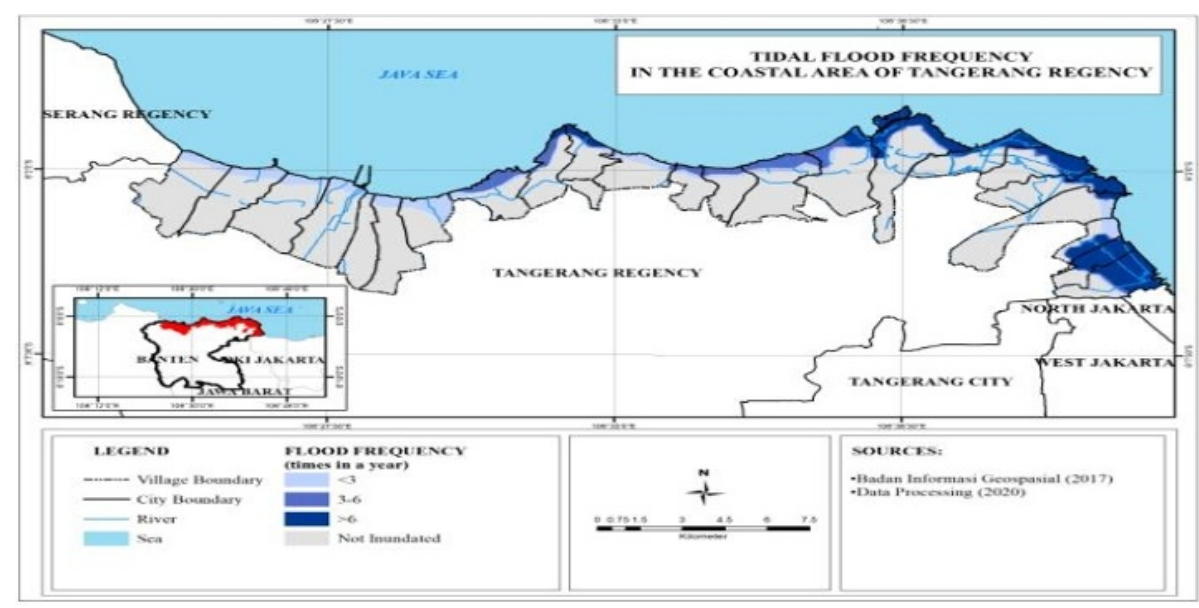

Fig. 4. Tidal flood frequency in coastal area of Tangerang Regency

\subsection{Tidal flood hazard in coastal area of Tangerang Regency}

Tidal flood hazard area is obtained by overlaying the three components of flood characteristics After doing the process, it is divided into four classes, non-hazardous, low, moderate, and high. It can be seen in Figure 5. Tangerang Regency is dominated by the nonhazardous class of hazard level. The class has an area of 9,727 hectares or $75 \%$ of the total coastal area of Tangerang Regency. The level of low-class hazard has an area of 1,031 hectares or $8 \%$ of the total coastal area of Tangerang Regency. The level of moderate class hazard has an area of 1,078 hectares or $8 \%$ of the total area of the coast of Tangerang Regency. While the high-class hazard level has an area of 1,149 hectares or $9 \%$ of the total coastal area of Tangerang Regency.

The non-hazardous class is a region that is not inundated by tidal flood. This region is far from the sea with a height of more than $40 \mathrm{~cm}$ above sea level. Hazard level may increase in some regions which close to the river mouth. Based on the survey, it is because rivers are media for the entry of seawater into the mainland. The increasing of hazard level can also be indicated by low altitude areas with an altitude less than $20 \mathrm{~cm}$ above sea level.

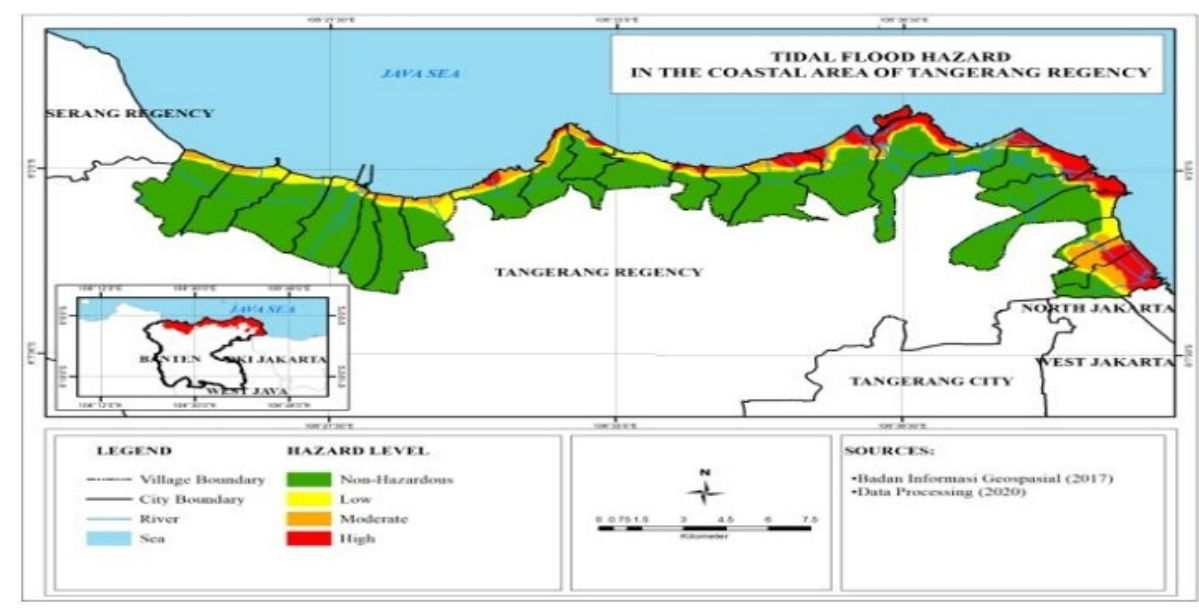

Fig. 5. Tidal flood hazard in coastal area of Tangerang Regency 
Hazard equilibrium value is used to discover how much a village is affected by flooding. It is obtained by processing the overlay result of the hazard level. The hazard equilibrium value is divided into three classes, namely low $(<1.50)$, moderate $(1.50-2.0)$, and high $(>2.0)$ based on the calculation results. It can be seen in Figure 6 .

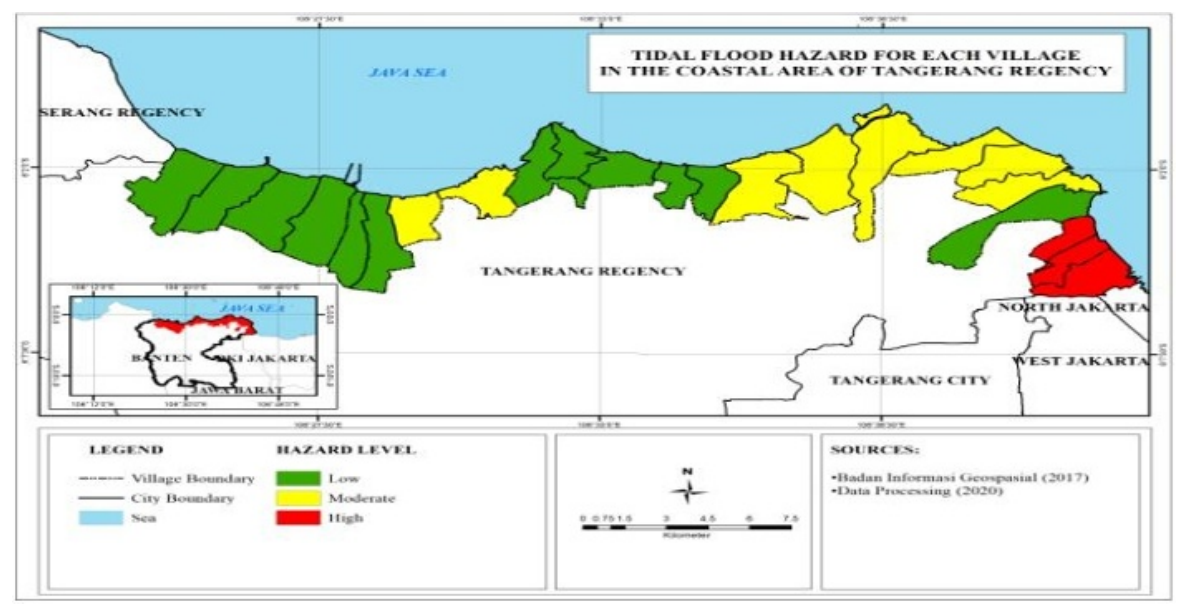

Fig. 6. Tidal flood hazard in coastal area of Tangerang Regency for each village

Low-class hazard is found in 12 villages in the coastal area of Tangerang Regency or 52\% of the total number of villages in the coastal area of Tangerang Regency. Villages that have a low-class of hazard are Marga Mulya Village, Muncung Village, Lontar Village, Sukawali Village, Salembaran Jaya Village, Kronjo Village, Patra Manggala Village, Karang Serang Village, Suryabahari Village, Pagedangan Ilir Village, Karang Anyar Village, and Tanjung Anom Village. The moderate class hazard is found in 8 villages in the coastal area of Tangerang Regency or $35 \%$ of the total number of villages in the coastal area of Tangerang Regency. The moderate class of hazard is owned by Ketapang Village, Lemo Village, Tanjung Burung Village, Kohod Village, Mauk Barat Village, Kramat Village, Tanjung Pasir Village, and Muara Village. Whereas for the high-class hazard level found in 3 villages in the coastal area of Tangerang Regency or $13 \%$ of the total number of villages in the coastal area of Tangerang Regency. Villages that have a high level of hazard are East Kosambi Village, West Kosambi Village, and Dadap Village.

\section{Conclusion}

Tangerang Regency is dominated by the non-hazardous class. This class has an area of 9,727 hectares or $75 \%$ of the total coastal area of Tangerang Regency. The low-class has an area of 1,031 hectares or $8 \%$ of the total coastal area of Tangerang Regency. The moderate class has an area of 1,078 hectares or $8 \%$ of the total area of the coast of Tangerang Regency. While the high-class has an area of 1,149 hectares or $9 \%$ of the total coastal area of Tangerang Regency. Hazard level may increase in some regions which close to the river mouth. The increasing of hazard level can also be indicated by low altitude area. Based on the calculation of hazard equilibrium value, coastal area of Tangerang Regency is dominated by low-class hazard level. There are 12 villages with low-class of hazard level. These villages are Marga Mulya Village, Muncung Village, Lontar Village, Sukawali Village, Salembaran Jaya 
Village, Kronjo Village, Patra Manggala Village, Karang Serang Village, Suryabahari Village, Pagedangan Ilir Village, Karang Anyar Village, and Tanjung Anom Village.

\section{References}

1. M. A. Marfai, Tidal flood hazard assessment: modeling in raster GIS, case in Western part of Semarang coastal area, Indonesian Journal of Geography, 61 25-38, (2004)

2. R. K. Chandra and R. D. Supriharjo, Rob Flood Disaster Mitigation in North Jakarta, J. Tek. Pomits, 21 25-30 (2013)

3. R. Rast, S. Finney, L. Cheng, J. Schmidt, K. Gerein, and A. Miller, Effects of the Moon on the Earth in the Past, Present and Future, USURJ Univ. Saskatchewan Undergrad. Res. J., 4 1 1-11 (2017)

4. Badan Nasional Penanggulangan Bencana, Disaster Prone Index, (2011)

5. N. Ikhsyan, C. Muryani, and P. Rintayati, Analysis of the Distribution, Impact and Adaptation of Communities to Rob Floods in East Semarang District and Gayamsari District, Semarang City, J. GeoEco, 32 145-156 (2017)

6. I. S. D. Sebayang and A. Kurniadi, Identification and Analysis of Damage to the Tanjung Pasir Coastline in Tangerang Regency, Banten., Civil Engineering, 4111 $20(2015)$

7. Badan Nasional Penanggulangan Bencana, Regulation of the Head of BNPB No. 02 of 2012 on General Guidelines for Disaster Risk Assessment. (2012).

8. S. Susilowati and N. R. T. Santita, Analysis of land use change and runoff coefficient on urban drainage discharge, Civil Engineering Media, 61 35-40 (2006) 